\title{
Increase of serum interleukin 6 and interferon $\gamma$ is associated with the number of impulses in patients with supraventricular arrhythmias treated with radiofrequency catheter ablation
}

\author{
Radek Pudila, Martina Vasatova ${ }^{b}$, Petr Parizek ${ }^{a}$, Ludek Hamana ${ }^{a}$, Lucie Horakova ${ }^{a}$, Vladimir Palicka ${ }^{b}$
}

\begin{abstract}
Background. Activation of the immune system plays a pathogenic role in the process of myocardial remodeling in patients with supraventricular arrhythmias. The intensity of this process is associated with the effectiveness of electrical cardioversion and radiofrequency catheter ablation (RFA). The aim of this study was to test the ability of the biochip microarray to detect immune parameters in patients with supraventricular arrhythmias undergoing RFA treatment.

Methods. We used a biochip-based microarray system to determine multiple immune parameters in a group of 35 patients who had undergone RFA for atrioventricular nodal reentry tachycardia (AVNRT), atrial flutter (AFL) and atrial fibrillation (AF).

Results. Before the procedure, serum IL- 6 and VEGF levels were significantly increased in patients with atrial fibrillation compared to patients with AVNRT (IL-6: $6.4 \pm 6.3 \mathrm{ng} / \mathrm{L}$ vs. $1.5 \pm 0.7 \mathrm{ng} / \mathrm{L}, P<0.01$;VEGF: $132.4 \pm 74 \mathrm{ng} / \mathrm{L}$ vs. $88.5 \pm 56.4 \mathrm{ng} / \mathrm{L}$, $P<0.01)$. After the procedure, serum IL-6, VEGF, IFN- $\gamma$ and MCP-1 levels significantly increased compared to baseline (IL-6: $5.2 \pm 4.8 \mathrm{ng} / \mathrm{L}$ vs. $2.9 \pm 2.1 \mathrm{ng} / \mathrm{L}, P<0.01$; VEGF: $195.8 \pm 160 \mathrm{ng} / \mathrm{L}$ vs. $119.8 \pm 110 \mathrm{ng} / \mathrm{L}, P<0.05 ; \mathrm{IFN}-\gamma: 3.1 \pm 1.2 \mathrm{ng} / \mathrm{L}$ vs. $2.3 \pm 0.6 \mathrm{ng} / \mathrm{L}, P<0.05 ; \mathrm{MCP}-1: 104.1 \pm 84.5 \mathrm{ng} / \mathrm{L}$ vs. $54.5 \pm 50 \mathrm{ng} / \mathrm{L}, P<0.05)$. Serum IL-6 and IFN- $\gamma$ were associated with the number of RFA applications (IL-6: $r=0.56, n$ 33; IFN- $-r=0.47, n$ 33).
\end{abstract}

Conclusions. This study showed that biochip-based microarray can be useful in the detection of immune activation in patients with arrhythmias and can detect myocardial injury after RF procedures.

Key words: cytokines, cardiology, radiofrequency catheter ablation, supraventricular arrhythmia, myocardial injury

Received: November 15, 2014; Accepted with revision: July 21, 2015; Available online: September 2, 2015

http://dx.doi.org/10.5507/bp.2015.038

${ }^{a} 7^{\text {st }}$ Deptartment of Internal Medicine - Cardioangiology, Faculty of Medicine in Hradec Kralove, Charles University in Prague, Hradec Kralove, Czech Republic

'Institute of Clinical Biochemistry and Diagnostics, Faculty of Medicine in Hradec Kralove, Charles University in Prague, Hradec Kralove, Czech Republic

Corresponding author: Radek Pudil, e-mail:pudilradek@yahoo.com

\section{INTRODUCTION}

Radiofrequency catheter ablation (RFA) therapy has become a standard therapy for a wide spectrum of cardiac arrhythmias. Radiofrequency current application causes minor myocardial damage due to thermal injury ${ }^{1}$. These lesions are considered to be small because of the low postprocedural troponin and creatine kinase levels. Histologic examination in the acute phase demonstrates the presence of coagulation necrosis of the myocardium, interstitial hemorrhage and edema, followed by infiltration of inflammatory cells. In the chronic phase, the lesions become fibrotic and fatty ${ }^{2}$. The motivation for investigating myocardial injury after RFA was (1) RF treatment of some arrhythmias, e.g. atrial fibrillation (AF) or right atrial flutter (AFL) requires an increased number of RF applications, and (2) a growing body of evidence suggesting a possible association of inflammation in initiation and perpetuation of atrial fibrillation.

Elevated serum levels of C-reactive protein, a systemic marker of inflammation, and interleukin 6 (IL-6), a proinflammatory cytokine, have been reported in patients with
$\mathrm{AF}\left(\right.$ ref. $\left.^{3-5}\right)$. Furthermore, C-reactive protein was found to predict a successful restoration of sinus rhythm in patients undergoing direct current cardioversion ${ }^{6,7}$. Serum levels of other markers (interleukin 8, P-selectin, tumor necrosis factor alpha, fibrinogen) have also been noted to be higher in patients with AF compared with controls in sinus rhythm ${ }^{8,9}$. The association between inflammation and AF has been derived from histological studies. The results of atrial biopsies taken from patients with AF compared with controls have provided evidence of inflammatory infiltrates and oxidative damage within the atrial tissue.

The majority of published studies have examined the association of immune system and AF but there is a dearth of data on immune system activation, atrial flutter and other supraventricular tachyarrhythmias. There is little evidence of C-reactive protein and IL-6 increase in patients presenting AFL (ref. ${ }^{10}$ ).

Owing to the possibility of adjusting the energy delivered, the radiofrequency catheter ablation procedure is a very useful model for testing the broad spectrum of cardiac markers and immune parameters.

The aims of this study were to: (1) evaluate whether 
this system is able to detect even small injuries caused by the RF procedure compared to established markers of myocardial necrosis, and (2) to investigate whether the measurement of the immune parameters using new biochip array technology can also detect differences in patients with various types of supraventricular arrhythmias undergoing RFA.

New biochip cytokine arrays provide assessment of a broad spectrum of immune pro- and anti-inflammatory cytokines [interleukin $1 \alpha($ IL- $1 \alpha)$, interleukin $1 \beta$ (IL-1 $\beta)$, interleukin 2 (IL-2), interleukin 4 (IL-4), interleukin 6 (IL-6), interleukin 8 (IL-8), interleukin 10 (IL-10), tumor necrosis factor alpha (TNF- $\alpha)$, which are modulators of inflammation and the healing process after the RFA treatment. This array can also be used for assessment of other parameters which can play an important role in the process of myocardial remodeling [vascular endothelial growth factor (VEGF), epidermal growth factor (EGF), and monocyte chemotactic protein 1 (MCP-1)].

\section{MATERIAL AND METHODS}

\section{Patients}

A total of 35 consecutive patients ( 21 men and 14 women, aged $54 \pm 14$ years, range 21 - 64) underwent RFA for symptomatic atrioventricular nodal reentry tachycardia (AVNRT, $\mathrm{n}=14$ ), atrial flutter (AFL, $\mathrm{n}=$ 11 ) and atrial fibrillation ( $A F, n=10)$. The control group consisted of 18 healthy blood donors with no history of cardiovascular disease (11 men and 6 women, aged 41 \pm 16 years, range 19 - 54). There were no gender difference between the study and control group, but the control group was younger $(P=0.05)$.

Patients were excluded from the study if they were likely to have elevated serologic markers of inflammation independent of the association with their arrhythmia: patients with a history of a myocardial infarction or elevated troponin levels within the previous 3 months, major trauma or surgery within the previous 3 months, any chronic inflammatory disease, chronic infectious diseases requiring treatment, any malignancy, any rheumatologic or infectious disease (including symptoms of common upper respiratory tract infection), or any other condition that would be expected to cause a fever, elevated white blood cell count, or elevated erythrocyte sedimentation rate.

The study protocol conformed to the ethical guidelines of the 1975 Declaration of Helsinki, and was approved by Ethics committee of our institution. Informed consent was obtained from each patient.

\section{Electrophysiology and ablation procedure}

The diagnostic electrophysiological study (EPS) was performed in the fasting state after all antiarrhythmic drugs had been discontinued for a period of at least five drug elimination half-times. Routinely, three 4F quadripolar electrode catheters were introduced via femoral vein and positioned under fluoroscopy at the right atrium, at the His bundle region and at the right ventricular apex. In all patients, a $6 \mathrm{~F}$ steerable decapolar catheter was placed in the coronary sinus. Previously described standard recording techniques, programmed stimulation methods, protocols and definitions were used ${ }^{1}$.

After initial location of the arrhythmia substrate, RF current was delivered using two types of catheters: conventional and irrigated catheters (irrigated catheters were used for the treatment of AF and AFL). The AVNRT were ablated, targeting the slow-pathway, RF ablation of the cavotricuspid isthmus was used to treat AFL, and isolation of pulmonary veins was used to treat AF. RF energy was generated at a frequency of $500 \mathrm{~Hz}$ by a conventional temperature or power controlled electrosurgical unit and was delivered between the distal electrode and a cutaneous indifferent disperse pad (maximum power: $30 \mathrm{~W}$ for AVNRT and AF, $45 \mathrm{~W}$ for AFL). Periprocedurally, patients with AF received anticoagulant and antithrombotic therapy with heparin.

\section{Blood samples}

Blood samples (before the procedure and $24 \mathrm{~h}$ later) were obtained from venous catheters, introduced into tube collectors containing no preservatives. Within $1 \mathrm{~h}$, the blood samples were centrifuged for $10 \mathrm{~min}$ at $2500 \mathrm{~g}$ and the supernatant was removed and kept at $-20^{\circ} \mathrm{C}$ until the assay was performed.

\section{Biomarker assessment}

High Sensitivity Cytokine Array kit for Evidence Investigator (Randox Laboratories, Crumlin, Northern Ireland) was used for the simultaneous measurement of human cytokines: IL-1 $\alpha$, IL-1 $\beta$, IL-2, IL-4, IL-6, IL-8, IL-10, VEGF, IFN $\gamma$, EGF, MCP-1, and TNF $\alpha$ in human serum.

This biochip technology uses the format of a sandwich immunoassay to detect cytokines. The solid-phase is represented by the biochip $\left(9 \mathrm{~mm}^{2}\right)$. The monoclonal capture antibodies specific for the analytes are bound and stabilized in predefined positions on the preactivated biochip surface, delimiting discrete test regions of antibodymicroarrays. Following incubation, the cytokines present in the sample (calibrator/control) bind to the corresponding discrete test regions and are detected after a second incubation with horseradish peroxidase - labeled detecting antibody multiconjugate.

The immunoreaction is detected by chemiluminescence after the reaction of hydrogen peroxide and luminol catalyzed by horseradish peroxidase. The light emitted by the discrete test regions is simultaneously recorded by a supercooled charge coupled device camera. Dedicated software quantifies, validates, and processes the results that are automatically archived by the system for retrospective access.

Cardiac troponin T (hsTnT) was measured by highsensitivity electrochemiluminiscence immunoassay using the TnT hs STAT assay for Elecsys 2010 analyzer (Roche Diagnostics, Mannheim, Germany) ${ }^{11}$. The hsTnT assay had an analytical range of $0.003-10 \mu \mathrm{g} / \mathrm{L}$. The cut-off value according to the manufacturer was $0.014 \mu \mathrm{g} / \mathrm{L}$ (i.e. the 99th percentile cut-off of healthy reference population values, $\mathrm{n}=616, \mathrm{CV}=9.0 \%$ ). 


\section{Statistical analysis}

Statistical analysis was performed by Statistica 5 program (Tulsa, USA). Normally distributed variables are expressed as means \pm standard deviation, while nonnormally distributed variables are expressed as median (interquartile range). Categorical variables are presented as percentages. Continuous variables were compared using Student's t-test, Mann-Whitney or Wilcoxon's tests, where appropriate.

The degree of association between continuous variables was calculated by Spearman rank correlation method. Linear regression was applied to evaluate the relationship between continuous variables. A $P$-value $<0.05$ was considered statistically significant.

\section{RESULTS}

\section{Procedural characteristics}

All patients underwent RFA without any complication. Characteristics of the RFA procedures are given in Table 1. The conventional type of RF catheter was used in 14 patients and the irrigated type of catheter was used in 21 patients treated for AF and AFL.

\section{Baseline serum immune parameter levels (Table 2)}

The analysis of the patient subgroups according to the type of the arrhythmia (AVNRT, AFL and AF) revealed significant differences. In patients with AF, serum IL-6 level was significantly increased compared to patients with AVNRT and patients with AFL. Similarly, serum VEGF level was increased in patients with AF when compared to patients with AVNRT. Serum IL-1 $\alpha$, IL-1 $\beta$, IL-2, IL-4, IL-10, TNF $\alpha$, IFN- $\gamma$ and MCP-1 levels were not different from the values of the control group.

\section{Postprocedural characteristics}

$24 \mathrm{~h}$ after the procedure, serum IL-6, VEGF, IFN- $\gamma$ and MCP-1 levels significantly increased when compared to baseline levels in all group. The most significant changes were observed in AF patients. Serum IL- $1 \alpha$, IL-1 $\beta$, IL2, IL-4, IL-8, IL-10, TNF $\alpha$ and EGF levels were without any significant change compared to baseline levels. The association of the postprocedural IL- 6 and IFN- $\gamma$ with the number of RF impulses was significant (IL-6: $\mathrm{r}=0.56$, n 33; IFN- $\gamma: r=0.47$, n 33, Fig. 1). The measurement of hsTnT was used as a standard marker to evaluate the size of the myocardial necrosis. Serum hsTnT significantly increased in all study groups, the most significant increase
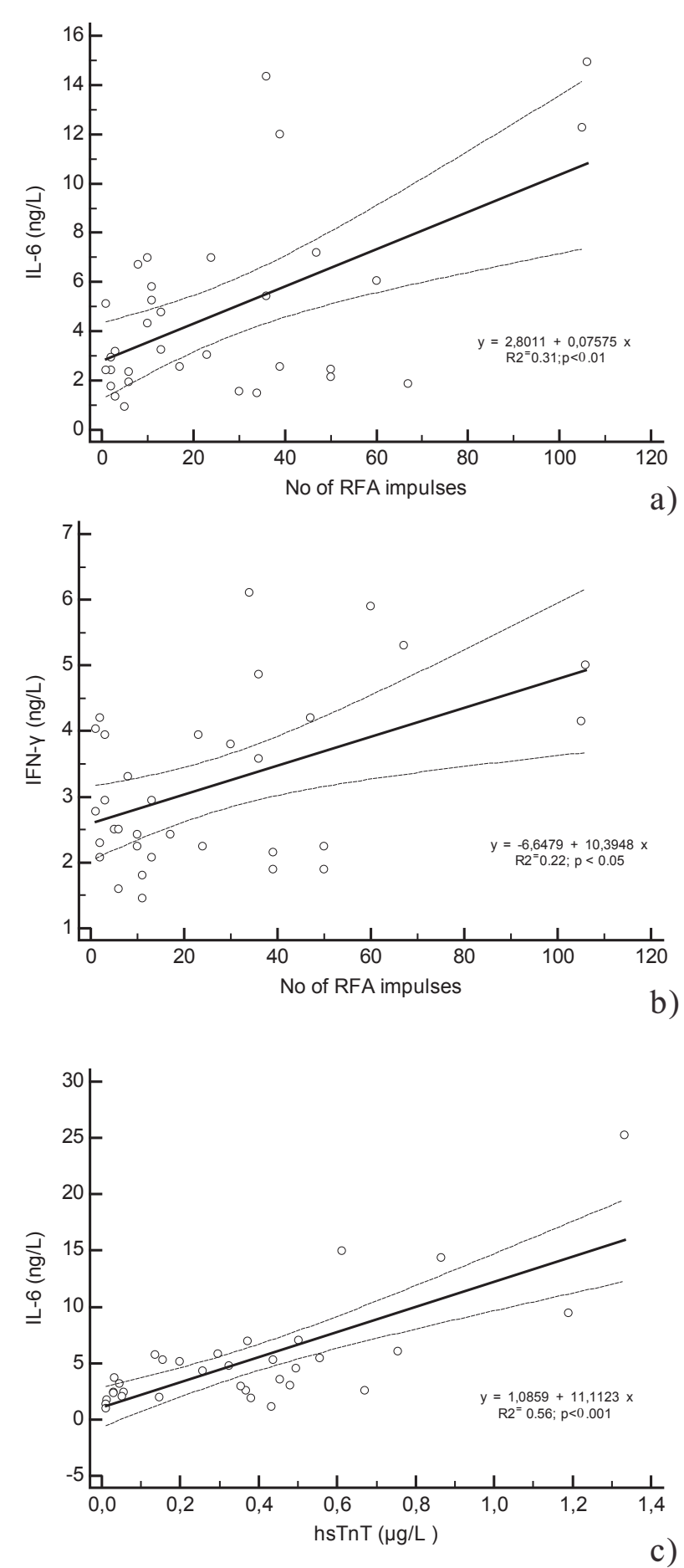

Fig. 1. Regression plots showing correlation between number of RF impulses and serum IL-6 level (a); serum IFN- $\gamma$ level (b) and relation of serum hsTnT and IL-6 levels (c); (regression lines with $95 \%$ confident intervals are indicated).

Table 1. Procedural characteristics.

\begin{tabular}{lcccc}
\hline & $\begin{array}{c}\text { All group }(\mathrm{n}=35) \\
\text { median }(1 \mathrm{Q}-3 \mathrm{Q})\end{array}$ & $\begin{array}{c}\text { AVNRT }(\mathrm{n}=14) \\
\text { median }(1 \mathrm{Q}-3 \mathrm{Q})\end{array}$ & $\begin{array}{c}\text { AFL }(\mathrm{n}=11) \\
\text { median (1Q-3Q) }\end{array}$ & $\begin{array}{c}\text { AF }(\mathrm{n}=10) \\
\text { median }(1 \mathrm{Q}-3 \mathrm{Q})\end{array}$ \\
\hline Total RFA & 431 & 236 & 370 & 4947 \\
duration time, & $(134-1414)$ & $(98-609)$ & $(200-469)$ & $(3913-5411)$ \\
Number & 13 & 9 & 12 & 55 \\
of RF lesions & $(6-37)$ & $(3-24)$ & $(10-16)$ & $(49-76)$ \\
\hline
\end{tabular}

Duration time in seconds, (median, $1 \mathrm{Q}$ and $3 \mathrm{Q}$ are indicated). 
Table 2. Serum IL-1 $\alpha$, IL-1 $\beta$, IL-2, IL-4, IL-6, IL-8, IL-10, VEGF, TNF $\alpha$, IFN- $\gamma$, EGF and MCP-1 levels in patients and control group.

\begin{tabular}{|c|c|c|c|c|c|c|c|c|c|c|}
\hline & \multirow{3}{*}{$\begin{array}{c}\text { Assay } \\
\text { analytical } \\
\text { range }^{\mathrm{a}} \\
\text { (analytical }^{\text {andivity) }}\end{array}$} & \multirow{3}{*}{$\begin{array}{c}\text { Controls } \\
\mathrm{X} \pm \mathrm{SD} \\
\text { median } \\
(1 \mathrm{Q}-3 \mathrm{Q})\end{array}$} & \multicolumn{8}{|c|}{ Patients } \\
\hline & & & \multicolumn{4}{|c|}{ Baseline } & \multicolumn{4}{|c|}{ Postprocedural } \\
\hline & & & $\begin{array}{c}\text { All group } \\
\mathrm{x} \pm \mathrm{SD} \\
\text { median } \\
(1 \mathrm{Q}-3 \mathrm{Q})\end{array}$ & $\begin{array}{c}\text { AVRNT } \\
\mathrm{X} \pm \mathrm{SD} \\
\text { median } \\
(1 \mathrm{Q}-3 \mathrm{Q})\end{array}$ & $\begin{array}{c}\mathrm{AFL} \\
\mathrm{X} \pm \mathrm{SD} \\
\text { median } \\
(1 \mathrm{Q}-3 \mathrm{Q})\end{array}$ & $\begin{array}{c}\mathrm{AF} \\
\mathrm{X} \pm \mathrm{SD} \\
\text { median } \\
(1 \mathrm{Q}-3 \mathrm{Q})\end{array}$ & $\begin{array}{c}\text { All group } \\
\mathrm{X} \pm \mathrm{SD} \\
\text { median } \\
(1 \mathrm{Q}-3 \mathrm{Q})\end{array}$ & $\begin{array}{c}\text { AVRNT } \\
\mathrm{X} \pm \mathrm{SD} \\
\text { median } \\
(1 \mathrm{Q}-3 \mathrm{Q})\end{array}$ & $\begin{array}{c}\text { AFL } \\
\mathrm{X} \pm \mathrm{SD} \\
\text { median } \\
(1 \mathrm{Q}-3 \mathrm{Q})\end{array}$ & $\begin{array}{c}\mathrm{AF} \\
\mathrm{X} \pm \mathrm{SD} \\
\text { median } \\
(1 \mathrm{Q}-3 \mathrm{Q})\end{array}$ \\
\hline $\begin{array}{l}\mathrm{IL}-1 \alpha \\
\mathrm{ng} / \mathrm{L}\end{array}$ & $\begin{array}{l}0-225 \\
(0.19)\end{array}$ & $\begin{array}{c}0.7 \pm 0.3 \\
0.6 \\
(0.5-0.7)\end{array}$ & $\begin{array}{c}0.9 \pm 1.3 \\
0.6 \\
(0.5-0.8)\end{array}$ & $\begin{array}{c}1.2 \pm 1.3 \\
0.7 \\
(0.5-0.9)\end{array}$ & $\begin{array}{c}0.5 \pm 0.1 \\
0.5 \\
(0.4-0.6)\end{array}$ & $\begin{array}{c}0.6 \pm 0.2 \\
0.5 \\
(0.4-0.6)\end{array}$ & $\begin{array}{c}1.2 \pm 2.1 \\
0.7 \\
(0.6-0.8)\end{array}$ & $\begin{array}{c}1.2 \pm 2.1 \\
0.7 \\
(0.6-0.8)\end{array}$ & $\begin{array}{c}0.9 \pm 0.6 \\
0.7 \\
(0.5-0.8)\end{array}$ & $\begin{array}{c}0.7 \pm 0.2 \\
0.6 \\
(0.5-0.7)\end{array}$ \\
\hline $\begin{array}{l}\mathrm{IL}-1 \beta \\
\mathrm{ng} / \mathrm{L}\end{array}$ & $\begin{array}{c}0-112.5 \\
(0.26)\end{array}$ & $\begin{array}{c}2.1 \pm 1.4 \\
1.6 \\
(1.5-1.8)\end{array}$ & $\begin{array}{c}2 \pm 1.9 \\
0.9 \\
(0.2-2.2)\end{array}$ & $\begin{array}{c}1.8 \pm 1.7 \\
0.8 \\
(0.6-1.3)\end{array}$ & $\begin{array}{c}3.1 \pm 2.6 \\
0.8 \\
(0.6-2)\end{array}$ & $\begin{array}{c}2.8 \pm 1.5 \\
0.8 \\
(0.7-2.5)\end{array}$ & $\begin{array}{c}2.5 \pm 2.3 \\
0.8 \\
(0.7-1.5)\end{array}$ & $\begin{array}{c}2.5 \pm 2.9 \\
0.7 \\
(0.6-1.1)\end{array}$ & $\begin{array}{c}2.7 \pm 3.1 \\
0.9 \\
(0.7-2.27)\end{array}$ & $\begin{array}{c}1.7 \pm 1.4 \\
1.2 \\
(0.8-1.7)\end{array}$ \\
\hline $\begin{array}{l}\text { IL-2 } \\
\text { ng/L }\end{array}$ & $\begin{array}{l}0-1200 \\
(0.90)\end{array}$ & $\begin{array}{c}5.8 \pm 3 \\
4.4 \\
(4.2-6.2)\end{array}$ & $\begin{array}{c}6.7 \pm 5.7 \\
4.4 \\
(4.2-4.6)\end{array}$ & $\begin{array}{c}4.1 \pm 0.7 \\
4.4 \\
(4.1-4.5)\end{array}$ & $\begin{array}{c}13.3 \pm 11.9 * \\
4.4 \\
(4.3-10.2)\end{array}$ & $\begin{array}{c}7.5 \pm 4.4^{*} \\
4.7 \\
(4.3-8.8)\end{array}$ & $\begin{array}{c}6.5 \pm 6.2 \\
4.3 \\
(3.9-5.08)\end{array}$ & $\begin{array}{c}4.9 \pm 0.9 \\
4.4 \\
(3.8-4.4)\end{array}$ & $\begin{array}{c}13.3 \pm 11.1 \\
4.6 \\
(4.3-6.4)\end{array}$ & $\begin{array}{c}7.6 \pm 3.3 \\
6 \\
(4.4-9.3)\end{array}$ \\
\hline $\begin{array}{l}\text { IL-4 } \\
\mathrm{ng} / \mathrm{L}\end{array}$ & $\begin{array}{l}0-1500 \\
(2.12)\end{array}$ & $\begin{array}{c}3.7 \pm 1.6 \\
3.6 \\
(2.8-3.9)\end{array}$ & $\begin{array}{c}4.1 \pm 1.1 \\
4.0 \\
(3.4-4.9)\end{array}$ & $\begin{array}{c}4.1 \pm 0.9 \\
4.2 \\
(3.8-4.9)\end{array}$ & $\begin{array}{c}4.3 \pm 1.3 \\
4.1 \\
(3.6-5.3)\end{array}$ & $\begin{array}{c}3.9 \pm 1.1 \\
3.8 \\
(3.1-4.8)\end{array}$ & $\begin{array}{c}4.5 \pm 3.3 \\
3.7 \\
(3.2-4.7)\end{array}$ & $\begin{array}{c}4.3 \pm 4.2 \\
3.7 \\
(3.2-4.8)\end{array}$ & $\begin{array}{c}3.7 \pm 0.7 \\
3.8 \\
(3.5-4)\end{array}$ & $\begin{array}{c}4.1 \pm 1.2 \\
4.2 \\
(3.2-4.6)\end{array}$ \\
\hline $\begin{array}{l}\text { IL-6 } \\
\text { ng/L }\end{array}$ & $\begin{array}{l}0-400 \\
(0.12)\end{array}$ & $\begin{array}{c}0.52 \pm 0.4 \\
0.4 \\
(0.3-0.6)\end{array}$ & $\begin{array}{c}2.9 \pm 2.1^{* *} \\
1.4 \\
(1-1.8)\end{array}$ & $\begin{array}{c}1.5 \pm 0.7 * * \\
1.3 \\
(1-1.8)\end{array}$ & $\begin{array}{c}3.1 \pm 2.3^{* *} \\
1.2 \\
(0.9-3.6)\end{array}$ & $\begin{array}{c}6.4 \pm 6.3^{* * *} \\
3.7 \\
(1.1-9.5)\end{array}$ & $\begin{array}{c}5.2 \pm 4.8^{* *} \\
3.5 \\
(2.3-5.8)\end{array}$ & $\begin{array}{c}2.1 \pm 1.8 * \\
2.6 \\
(1.9-5.2)\end{array}$ & $\begin{array}{c}6.2 \pm 3.8 * * \\
4.8 \\
(3.1-6.6)\end{array}$ & $\begin{array}{c}8.4 \pm 7.6^{* *} \\
5.8 \\
(2.3-10.8)\end{array}$ \\
\hline $\begin{array}{l}\text { IL-8 } \\
\text { ng/L }\end{array}$ & $\begin{array}{l}0-1450 \\
(0.36)\end{array}$ & $\begin{array}{c}4.8 \pm 1.7 \\
4.6 \\
(3.1-6.2)\end{array}$ & $\begin{array}{c}12.1 \pm 7.6^{* * *} \\
9.4 \\
(7.2-14.7)\end{array}$ & $\begin{array}{c}9.9 \pm 4.2 * \\
8.5 \\
(5.4-13.7)\end{array}$ & $\begin{array}{c}14 \pm 12.1^{* *} \\
9.6 \\
(7.6-13.6)\end{array}$ & $\begin{array}{c}15.4 \pm 7.4^{* * *} \\
13.5 \\
(8.9-19.9)\end{array}$ & $\begin{array}{c}14.1 \pm 10 \\
8.3 \\
(5.6-22.6)\end{array}$ & $\begin{array}{c}11.1 \pm 14 \\
10.8 \\
(6.8-16.7)\end{array}$ & $\begin{array}{c}15.7 \pm 7.9 \\
9.1 \\
(5.6-16.4)\end{array}$ & $\begin{array}{c}16.7 \pm 11.7 \\
6.5 \\
(5.8-17.2)\end{array}$ \\
\hline $\begin{array}{l}\mathrm{IL}-10 \\
\mathrm{ng} / \mathrm{L}\end{array}$ & $\begin{array}{l}0-450 \\
(0.37)\end{array}$ & $\begin{array}{c}2.6 \pm 2.4 \\
1.2 \\
(1.1-1.6)\end{array}$ & $\begin{array}{c}1.3 \pm 0.4 \\
1.2 \\
(0.9-1.3)\end{array}$ & $\begin{array}{c}1.3 \pm 0.5 \\
1.2 \\
(0.9-1.3)\end{array}$ & $\begin{array}{c}1.2 \pm 0.3 \\
1.2 \\
(1.1-1.3)\end{array}$ & $\begin{array}{c}1.2 \pm 0.2 \\
1.2 \\
(1.1-1.3)\end{array}$ & $\begin{array}{c}1.8 \pm 1.6 \\
1.3 \\
(1-1.7)\end{array}$ & $\begin{array}{c}2.1 \pm 2 \\
1.3 \\
(1-1.5)\end{array}$ & $\begin{array}{c}1.7 \pm 0.9 \\
1.3 \\
(1-1.9)\end{array}$ & $\begin{array}{c}1.4 \pm 0.5 \\
1.1 \\
(0.9-1.7)\end{array}$ \\
\hline $\begin{array}{l}\text { VEGF } \\
\mathrm{ng} / \mathrm{L}\end{array}$ & $\begin{array}{l}0-1000 \\
(1.53)\end{array}$ & $\begin{array}{c}37.7 \pm 27.5 \\
20.3 \\
(14.9-40.1)\end{array}$ & $\begin{array}{c}119.8 \pm 110 * * \\
95.4 \\
(49.9-150.1)\end{array}$ & $\begin{array}{c}88.5 \pm 56.4^{*} \\
66.2 \\
(42-141.9)\end{array}$ & $\begin{array}{c}132.4 \pm 74 * * \\
95.8 \\
(93.3-154.8)\end{array}$ & $\begin{array}{c}184.4 \pm 180 * * \\
118.4 \\
(75.7-166.9)\end{array}$ & $\begin{array}{c}195.8 \pm 160 * \\
148.1 \\
(82.1-251)\end{array}$ & $\begin{array}{c}125.3 \pm 83.8 * \\
94.7 \\
(65.8-111.1)\end{array}$ & $\begin{array}{c}148.2 \pm 135^{*} \\
170.8 \\
(111.2-285.3)\end{array}$ & $\begin{array}{c}154.6 \pm 129 * \\
132.3 \\
(57.1-173.7)\end{array}$ \\
\hline $\begin{array}{l}\text { IFN- } \gamma \\
\mathrm{ng} / \mathrm{L}\end{array}$ & $\begin{array}{l}0-600 \\
(0.44)\end{array}$ & $\begin{array}{c}2.7 \pm 1 \\
3 \\
(1.9-3.7)\end{array}$ & $\begin{array}{c}2.3 \pm 0.6 \\
2.3 \\
(2.1-2.4)\end{array}$ & $\begin{array}{c}2.5 \pm 0.8 \\
2.2 \\
(2.1-2.7)\end{array}$ & $\begin{array}{c}2.4 \pm 0.4 \\
2.1 \\
(2-2.4)\end{array}$ & $\begin{array}{c}2.1 \pm 0.1 \\
2.2 \\
(2-2.5)\end{array}$ & $\begin{array}{c}3.1 \pm 1.2^{*} \\
2.7 \\
(2.2-3.9)\end{array}$ & $\begin{array}{c}2.5 \pm 0.5^{*} \\
2.4 \\
(2.2-2.4)\end{array}$ & $\begin{array}{c}2.9 \pm 1.1 \\
2.8 \\
(2.1-3.6)\end{array}$ & $\begin{array}{c}4.1 \pm 1.5^{*} \\
4 \\
(3.4-4.4)\end{array}$ \\
\hline $\begin{array}{l}\text { TNF } \alpha \\
\text { ng/L }\end{array}$ & $\begin{array}{l}0-600 \\
(0.59)\end{array}$ & $\begin{array}{c}4.4 \pm 1.4 \\
4.4 \\
(4.3-4.9)\end{array}$ & $\begin{array}{c}3.2 \pm 1.7 \\
2.7 \\
(2.1-3.3)\end{array}$ & $\begin{array}{c}3.1 \pm 1.5 \\
2.5 \\
(2.1-3.4)\end{array}$ & $\begin{array}{c}2.4 \pm 0.4 \\
2.3 \\
(2.1-2.8)\end{array}$ & $\begin{array}{c}4 \pm 2.3 \\
2.7 \\
(2.6-4.9)\end{array}$ & $\begin{array}{c}3.3 \pm 1.5 \\
2.8 \\
(2.3-3.9)\end{array}$ & $\begin{array}{c}3.9 \pm 1.6 \\
2.9 \\
(2.4-3.8)\end{array}$ & $\begin{array}{c}2.9 \pm 0.8 \\
2.5 \\
(2.3-3.6)\end{array}$ & $\begin{array}{c}3.7 \pm 1.7 \\
2.9 \\
(2.6-4.8)\end{array}$ \\
\hline $\begin{array}{l}\text { MCP1 } \\
\mathrm{ng} / \mathrm{L}\end{array}$ & $\begin{array}{l}0-500 \\
(0.66)\end{array}$ & $\begin{array}{c}153.3 \pm 51.8 \\
138.4 \\
(114-187.7)\end{array}$ & $\begin{array}{c}190.3 \pm 52.5 \\
173.9 \\
(152-237.1)\end{array}$ & $\begin{array}{c}197.1 \pm 55.6 \\
184.1 \\
(155.3-238.3)\end{array}$ & $\begin{array}{c}176.1 \pm 40.1 \\
166.2 \\
(153.7-196.8)\end{array}$ & $\begin{array}{c}184.9 \pm 50.1 \\
178.6 \\
(147-237.2)\end{array}$ & $\begin{array}{c}186 \pm 86.3 \\
175.1 \\
(115-226.1)\end{array}$ & $\begin{array}{c}192.4 \pm 80.1 \\
211.4 \\
(168-271.1)\end{array}$ & $\begin{array}{c}187.3 \pm 50 \\
188.7 \\
(82.4-220)\end{array}$ & $\begin{array}{c}196.4 \pm 47.2 \\
85 \\
(65.8-231.1)\end{array}$ \\
\hline $\begin{array}{l}\mathrm{EGF} \\
\mathrm{ng} / \mathrm{L}\end{array}$ & $\begin{array}{l}0-450 \\
(1.04)\end{array}$ & $\begin{array}{c}13.7 \pm 12.5 \\
2.8 \\
(1.9-9.4)\end{array}$ & $\begin{array}{c}54.5 \pm 50 * \\
19.3 \\
(13-59.4)\end{array}$ & $\begin{array}{c}19.5 \pm 18.9 * \\
9.1 \\
(3.2-29.4)\end{array}$ & $\begin{array}{c}44.6 \pm 40.1 * \\
22.7 \\
(14.8-41.6)\end{array}$ & $\begin{array}{c}69 \pm 67.3 * * \\
21.5 \\
(14.5-82.6)\end{array}$ & $\begin{array}{c}104.1 \pm 84.5^{*} \\
82.8 \\
(41-138.2)\end{array}$ & $\begin{array}{c}70.9 \pm 66.2 * \\
113.1 \\
(75.4-160.2)\end{array}$ & $\begin{array}{c}78.9 \pm 44.3 * \\
72.1 \\
(38.7-118.1)\end{array}$ & $\begin{array}{c}100.9 \pm 100 * \\
52.3 \\
(34-102.5)\end{array}$ \\
\hline
\end{tabular}

${ }^{a}$ Manufacturer analytical range, ${ }^{b}$ Analytical sensitivity defined as the lowest concentration calculated from 20 replicates of a sample with imprecision of $\leq 20 \%$, (average data \pm standard deviation, median, $1 \mathrm{Q}$ and $3 \mathrm{Q}$ are indicated), ${ }^{*} P<0.05, * * P<0.01$.

was noticed in patients with atrial fibrillation [AVNRT: 0.004 (0.003-0.0077) $\mu \mathrm{g} / \mathrm{L}$ vs. $0.12(0.036-0.317) \mu \mathrm{g} / \mathrm{L}$, $P=0.0001$; AFL: $0.01(0.003-0.018) \mu \mathrm{g} / \mathrm{L}$ vs. $0.26(0.25-$ $0.43) \mu \mathrm{g} / \mathrm{L}, P=0.03$; AF: $0.005(0.004-0.01) \mu \mathrm{g} / \mathrm{L}$ vs. 0.71 $(0.55-1.26) \mu \mathrm{g} / \mathrm{L}, P=0.0078]$.

\section{DISCUSSION}

Increased pro-inflammatory cytokine (IL-6, IL-8), VEGF and EGF levels in patients with AF has been described and is attributed to persistent inflammation in atrial myocardium ${ }^{3-5,8,9}$. Our study also showed increase in serum IL-6, IL-8, VEGF and EGF levels compared to healthy controls but thisis limited because of the slightly different age of the groups. However all these observations are in accordance with the studies of atrial biopsy specimens taken from patients with AF showing the presence of histological abnormalities compatible with myocarditis, less frequently with non-inflammatory cardiomyopathy or with fibrotic changes ${ }^{12}$. Furthermore, we observed increased immune activity in patients with AFL (a small increase in serum IL-6, VEGF and EGF). All these findings support the hypothesis of the important role of inflammation in perpetuation of the arrhythmias ${ }^{8}$.

The postprocedural increase in immune parameters was probably caused by tissue injury as a result of RFA. It has been shown that the ablated lesions are hemispherical and measured about 2-4 diameter and 1 to $6 \mathrm{~mm}$ in depth. Histological examinations demonstrated the presence of central coagulation necrosis, interstitial hemorrhage and edema, followed by infiltration of inflammatory cells ${ }^{13}$. 
The number of RF impulses increases in patients with AFL and AF. Therefore, the RF procedure can serve as a sensitive model for evaluating the sensitivity of cardiac markers to detect minor small injuries. This concept was proven in studies with cardiac troponins ${ }^{14,15}$, creatine kinase ${ }^{16}$ and novel markers, e.g. glycogen phosphorylase BB, and fatty acid binding protein ${ }^{17}$. High sensitivity cardiac troponin $\mathrm{T}$ is considered to be a gold standard at this setting. Therefore, we evaluated the association of serum cytokine markers with the number of RF applications and with hsTnT level. We found an association of the postprocedural IL- 6 and IFN- $\gamma$ with the number of RF impulses. The significant association of IL- 6 with hsTnT levels ( $r$ $=0.75, \mathrm{n} 33, P<0.05)$ suggests the possibility of IL-6 as reflecting the magnitude of the myocardial injury.

This study has several limitations. First, it was a relatively small number of patients. This fact precluded analyzing the association of immune parameter levels to myocardial function and evaluating the long-term clinical result of RFA. Second, although we excluded patients with known or clinically evident inflammatory conditions, we cannot absolutely exclude the possibility that some patients had subclinical inflammatory disease. Third, in addition to myocardial necrosis, other peri-procedural factors such as the invasive procedure itself, the administered volume, contrast dye, and fluoroscopy time may have contributed to immune parameter increase.

Despite the limitations, the study showed that using the biochip array system, (1) the presence of atrial fibrillation is associated with significant immune system activation; (2) even a minor degree of myocardial injury caused by RFA is associated with a significant increase in IL-6, IFN- $\gamma$, VEGF and EGF, this increase persists for $24 \mathrm{~h}$ after the procedure; (3) serum IL-6 and IFN- $\gamma$ levels correlates with the number of RF impulses and serum hsTnT. For this reason, they can serve as a useful tool to quantify this type of myocardial injury.

The results of this study emphasise the role of cytokines in patients with supraventricular arrhythmias. It showed that biochip microarray can detect minor changes in serum immune parameter levels. It also raises important issues concerning the efficacy and safety of RFA with the aim of minimizing extent of myocardial injury.

\section{CONCLUSIONS}

The combined simultaneous assessment of 12 cytokines and growth factors have provided for the first time, a tool for the evaluation of the immune system activation in patients with arrhythmias.

Acknowledgement: This work was supported by the research project PRVOUK P 37/03 of Charles University Prague, Faculty of Medicine in Hradec Kralove.

Ethical approval for this study was provided by Ethical Committee of Charles University Prague, Medical Faculty Hradec Kralove, Czech Republic.
Author contributions: MV: biochemical analysis; RP: manuscript editing, statistical analysis; PP, LH: radiofrequency procedures.

Conflict of interest statement: The authors state that there are no conflicts of interest regarding the publication of this article.

\section{REFERENCES}

1. Morady F. Radio-frequency ablation as treatment for cardiac arrhythmias. N Engl J Med 1999;340:534-44.

2. Tanno K, Kobayashi Y, Kurano K, Kikushima S, Yazawa T, Baba T, Inoue S, Mukai H, Katagiri T. Histopathology of canine hearts subjected to catheter ablation using radiofrequency energy. Jpn Circ J 1994;58:123-35.

3. Ellinor PT, Low A, Patton KK, Shea MA, Macrae CA. C-Reactive protein in lone atrial fibrillation. Am J Cardiol 2006;97:1346-50.

4. Conway DS, Buggins P, Hughes E, Lip GY J. Relationship of interleukin- 6 and C-reactive protein to the prothrombotic state in chronic atrial fibrillation. Am Coll Cardiol 2004;43:2075-82.

5. Brueckmann M, Wolpert C, Bertsch T, Sueselbeck T, Liebetrau C, Kaden JJ, Huhle G, Neumaier M, Borggrefe M, Haase KK. Markers of myocardial damage, tissue healing, and inflammation after radiofrequency catheter ablation of atrial tachyarrhythmias. J Cardiovasc Electrophysiol 2004;15:686-91.

6. Liuba I, Ahlmroth H, Jonasson L, Englund A, Jönsson A, Säfström K, Walfridsson $\mathrm{H}$. Source of inflammatory markers in patients with atrial fibrillation. Europace 2008;10:848-53.

7. Letsas K, Weber R, Burkle G, Mihas CC, Minners J, Kalusche D, Arentz T. Pre-ablative predictors of atrial fibrillation recurrence following pulmonary vein isolation: the potential role of inflammation. Europace 2009;11:158-63.

8. Issac T, Dokaninish H, Lakkish MM. Role of inflammation in initiation and perpetuation of atrial fibrillation: a systematic review of the published data. J Am Coll Cardiol 2007;50:2021-8.

9. Stein A, Wessling G, Diesenhofer I, Busch G, Steppich B, Estner H, Zrenner B, Schmitt C, Braun S, Schomig A, Ott I. Systemic inflammatory changes after pulmonary vein radiofrequency ablation do not alter stem cell mobilization. Europace 2008;10:444-9.

10. Marcus GM, Smith L, Glidden D, Wilson E, McCabe JM, Whiteman D, Tseng ZH, Badhwar N, Lee BK, Lee RJ, Scheinman MM, Olgin JE. Markers of Inflammation Before and After Curative Ablation of Atrial Flutter. Heart Rhythm 2008;5:215-21.

11. Giannitsis E, Kurz K, Hallermayer K, Jarausch J, Jaffe A, Katus HA. Analytical validation of a high-sensitivity cardiac troponin $T$ assay. Clin Chem 2010;56:254-61.

12. Frustaci A, Chimenti C, Bellocci F, Morgante E, Russo AM, Maseri A. Histological substrate of atrial biopsies in patients with lone atrial fibrillation. Circulation 1997; 96:1180-4.

13. Aviles RJ, Martin DO, Apperson-Hansen C, Houghtaling PL, Rautaharju P, Kronmal RA, Tracy RP, Van Wagoner DR, Psaty BM, Lauer MS, Chung MK. Inflammation as a Risk Factor for Atrial Fibrillation. Circulation 2003;104:2886.

14. Emkanjoo Z, Mottayden M, Givtaj N, Alasti M, Arya A, Haghjoo M, Fazelifar AF, Alizadeh A, Sadr-Ameli MA. Evaluation of post-radiofrequency myocardial injury by measuring cardiac troponin I levels. Int J Cardiol 2007;117:173-7.

15. Vasatova M, Pudil R, Tichy M, Buchler T, Horacek JM, Haman L, Parizek P, Palicka V. High-sensitivity troponin T as a marker of myocardial injury after radiofrequency catheter ablation. Ann Clin Biochem 2011;48:38-40.

16. Haines DE, Whayne JG, Walker J, Nath S, Bruns D. The effect of radiofrequency catheter ablation on myocardial creatine kinase activity. J Cardiovasc Electrophysiol 1995;6:79-88.

17. Pudil R, Pařízek $P$, Tichy $M$, Haman $L$, Horaková $L$, Ulrychova $M$, Vojacek J, Palicka V. Use of the biochip microarray system in detection of myocardial injury caused by radiofrequency catheter ablation. Clin Chem Lab Med 2008;46:1726-8. 